\title{
KONTRIBUSI KEMAMPUAN GURU TERHADAP PRESTASI MATEMATIKA PESERTA DIDIK
}

\author{
The Contribution of Teacher Abilityto Students' Mathematics Achievements
}

\author{
Sumaryanta \\ PPPPTK Matematika, Jln. Kaliurang Km. 6 Sambisari, Condongcatur, \\ Depok, Sleman, Yogyakarta,0274-881717, 55281, Indonesia \\ maryanta01@gmail.com
}

\begin{abstract}
Teachers are stated as essential factor for student's achievement but there has not been enough research stating how much they really contribute. This study aims to identify teacher's ability contribution to student's mathematics learning achievement. This research is an ex post facto research conducted from March to November 2019. The population of this study includes junior high school mathematics teachers, senior high school mathematics teachers, and vocational school mathematics teachers in Indonesia. The research sample consisted of 858 teachers. Teacher'ability examined in this study is focused on 3 (three) points, namely: basic mathematics skills, ability to solve questions equivalent to national examination $(U N)$, and ability to solve HOTs test. Data were collected by tests and the results were analyzed by regression analysis techniques. The results showed simultaneouslythat teacher'basic mathematics skills, teacher'abilityto solve UN and HOTs questions contributed directly (very significantly/sig. 0.00) to the students' learning achievements, by $26.7 \%$, with a regression equation $Y=28,527+$ 0.023 MatDas + 0.037 UN + 0.154 HOTs.
\end{abstract}

Keywords: teacher ability, contribution, student' mathematics achievement

\begin{abstract}
ABSTRAK
Guru dinyatakan sebagai faktor esensial terhadap prestasi peserta didik tetapi belum adacukup penelitian yang menyatakan seberapa besar sesungguhnya kontribusi guru tersebut. Penelitian ini bertujuan mengidentifikasi kontribusi kompetensi guru terhadap prestasi belajar matematika peserta didik. Penelitian ini merupakan penelitian ex post facto yang dilaksanakan dari bulan Maret sampai dengan November 2019. Populasi penelitian ini meliputi guru matematika SMP, guru matematika SMA, dan guru matematika SMK di Indonesia. Sampel penelitian terdiri dari 1.223orang guru. Kompetensi guru yang dikaji dalam penelitian ini difokuskan pada 3 (tiga) hal, yaitu: kemampuan matematika dasar, kemampuan menyelesaikan soal setara ujian nasional, dan kemampuan menyelesaikan soal HOTs. Data dikumpulkan dengan tes dan hasilnya dianalisis dengan teknik analisis regresi. Hasil penelitian menunjukkansecara simultan kemampuan matematika dasar guru, kemampuan guru menyelesaikan soal UN, dan HOTs berkontribusi langsung (secara sangat signifikan/sig. 0.001) terhadap pencapaian prestasi belajar peserta didik, yaitu sebesar $26.7 \%$, dengan persamaan regresiY $=28.527+0.023$ MatDas + 0.037 UN + 0.154 HOTs
\end{abstract}

Kata kunci: kemampuan guru, kontribusi, prestasi matematika peserta didik

\section{PENDAHULUAN}

Revolusi industri 4.0 merupakan salah satu isu paling kuat dalam perjalanan kehidupan manusia saat ini(Morrar, Arman \& Mousa, 2017: 12). Revolusi industri 4.0 yang didorong teknologi cyberphysical, internet of things, cloud computing, and cognitive computing(Sidiq, dkk, 2019) telah mengaburkan batas antara dunia fisik, digital, dan biologis (Hussin, 2018: 92). Revolusi industri 4.0 yang ditandai adanya cyber dan kolaborasi manufaktur (Hermann et al, 2016; Afrianto, 2018:3) telah merubah hampir seluruh sendi-sendi kehidupan manusia. Tidak saja dalam bidang industri, revolusi industri 4.0 telah berdampak luas di bidang akademik (Plessis, 2017: 9), khususnya bidang pendidikan (Hussin, A.A., 2018: 92). Pembaharuan pendidikan di era revolusi industri 4.0 merupakan tantangan sekaligus harapan baru bagi kontribusi pendidikan yang lebih signifikan untuk membangun peradaban. 
Tuntutan perubahan sebagai dampak revolusi industri terjadi di hampir seluruh bidang pendidikan, termasuk pendidikan matematika. Revolusi industri 4.0 menghendaki pembelajaran matematika yang berbeda dengan praktik pembelajaran tradisional selama ini (Warohidah \& Kusuma, 2019: 109). Pendidikan matematika dituntut mampu bersikap proaktif mengantisipasi sekaligus mengambil manfaat dari dinamika perubahan di era revolusi industri 4.0 ini. Hal ini selaras dengan karakteristik matematika dimana matematika berkembang seiring dengan kebutuhan dan perkembangan peradapan manusia (Fathalani, 2009: 75). Matematika merupakan mata pelajaran penting dalam sistem pendidikan sekaligus dalam kehidupan sehari-hari (Sholihah \& Mahmudi, 2015:176). Matematika adalah produk budaya, dalam arti bahwa keseluruhan isinya, arahannya terhadap gerakan, merespons tekanan masyarakat (Ernest, 1997: 16). Matematika mewarnai dan diwarnai budaya manusia dimana matematika berkembang seiring dengan perkembangan produk budaya manusia, dan budaya manusia juga berkembang sebagai dampak kontribusi matematika (Sujono, 1988: 11). Kehadiran revolusi industri 4.0 telah menghadirkan tantangan sekaligus peluang bagi pendidikan matematika agar menjadi lebih fungsional untuk kehidupan.

Tingginya tuntutan terhadap pendidikan matematika saat ini belum mampu diimbangi kualitas proses dan hasil belajar matematika peserta didik.Berbagai temuan menunjukkan bahwa kualitas pembelajaran matematika tidak cukup baik. Secara nasional hasil matematika peserta didik rendah, dikawasan Asia Tenggara prestasi belajar matematika di Indonesia tertinggal, dan secara internasional daya saing matematika peserta didik juga rendah. Secara nasional, dalam tigatahun terakhir hasil UN matematika peserta didik rendah, seperti tersaji pada Gambar 1. berikut.

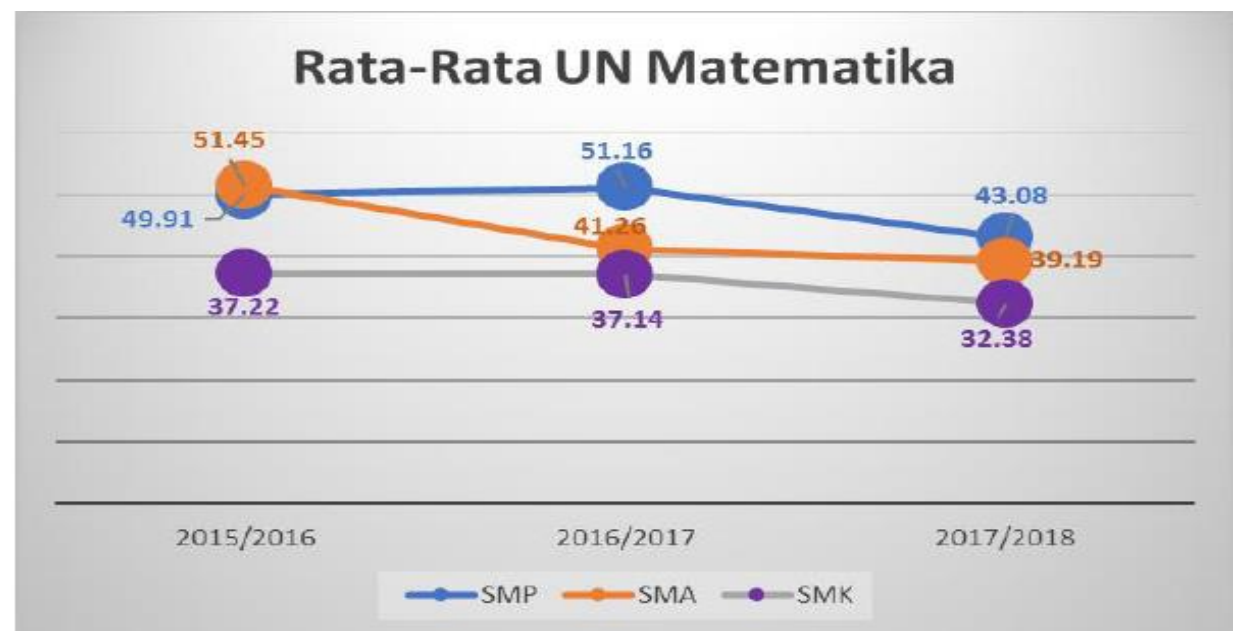

Gambar 1. Hasil UN Matematika Peserta Didik

Sumber: Sumaryanta (2019: 545)

Dikawasan Asia Tenggara, prestasi belajar matematika cukup tertinggal dibandingkan negara-negara di kawasan Asia Tenggara. Salah satu rendahnya kualitas belajar matematika Indonesia dapat dilihat pada hasil tes PISA di bidang matematika, capaian peserta didik Indonesia hampir selalu tertinggal dibanding negara-negara lain di kawasan Asia Tenggara. Paling akhir, hasil PISA tahun 2018pada bidang matematika peringkat Indonesia rendah, ditunjukkan Tabel 1.

Tabel 1. Skor dan Peringkat PISATahun 2018 Bidang Matematika

\begin{tabular}{clcc}
\hline No & Negara & Rata-rata skor & Peringkat \\
\hline 1. & Singapura & 569 & 2 \\
\hline 2. & Malaysia & 440 & 47 \\
\hline 3. & Brunai Darusalam & 430 & 51 \\
\hline 4. & Thailand & 419 & 57 \\
\hline 5. & Indonesia & 379 & 72 \\
\hline 6. & Philipina & 353 & 77 \\
\hline & & Skor: 0 $-\mathbf{6 0 0}$ & \\
& & Rata-rata: $\mathbf{4 8 9}$ &
\end{tabular}

Sumber: OECD, 2019 
Secara internasional, laporan Bank Dunia tahun 2018 menunjukkan bahwa perolehan PISA peserta dari Indonesia jauh lebih rendah dari rata-rata negara OECD (Organization for Economic Cooperation and Development, suatu organisasi internasional yang bergerak di bidang kerjasama ekonomi dan pembangunan yang memiliki 35 negara anggota, sebagian besar negara anggota OECD adalah negara-negara maju, namun ada juga beberapa negara berkembang yang tergabung didalamnya). Posisi Indonesia dibandingkan beberapa negara OECD lain terlihat pada Gambar 2.

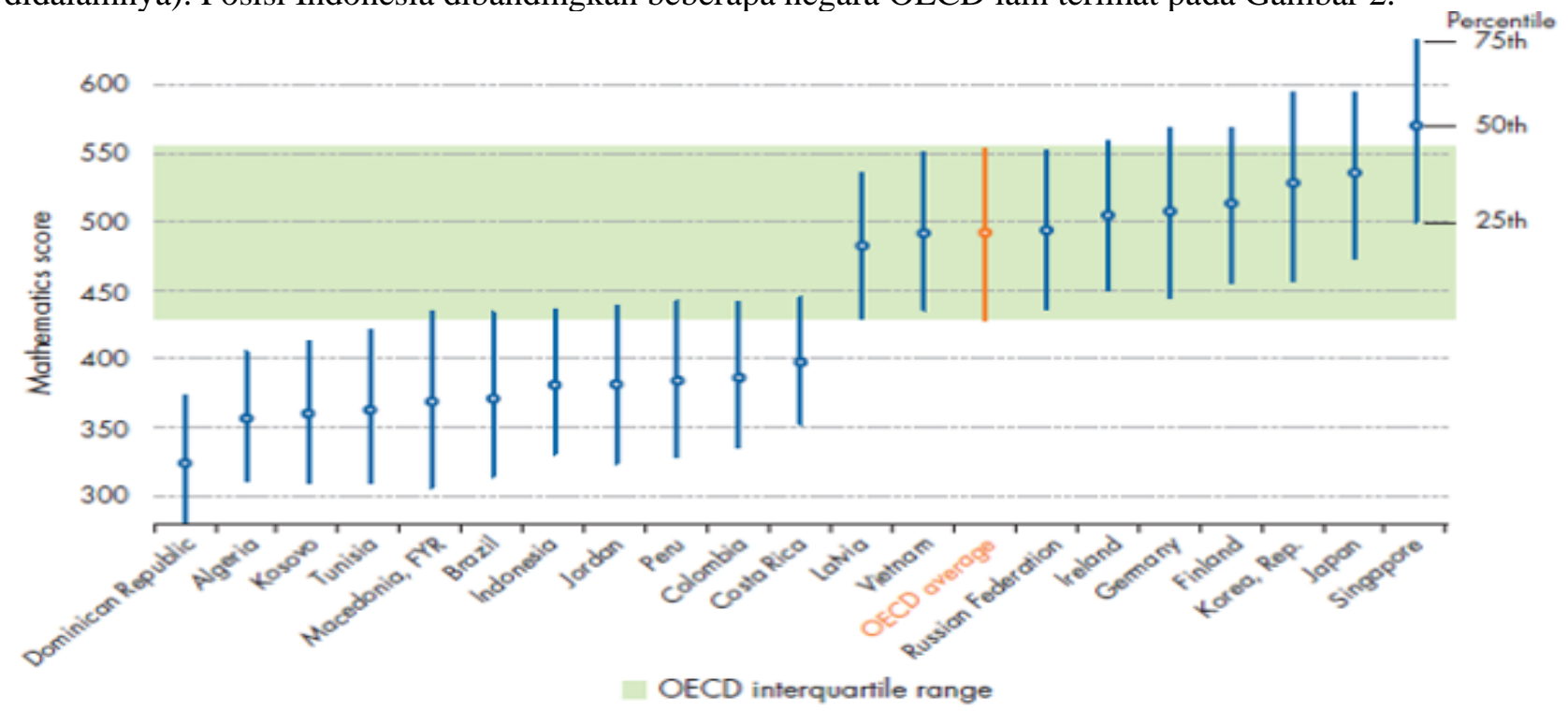

Gambar 2. Performa Percentil K2-25, 50, dan 75 pada Penilaian PISA Tahun 2015

(Sumber: Laporan Bank Dunia tahun 2018 tentang "World Development Report:

Learning to Realize Education's Promise")

Gambar 2 menunjukkan posisi capaian peserta didik Indonesia jauh dibawah negara-negara OECD. Bahkan, dari Gambar 3 terlihat bahwa capaian nilai terbaik dari peserta didik Indonesia hanya sama dengan nilai terjelek dari negara-negara OECD. Hasil ini tentu harus menjadi perhatian seluruh stakeholder pendidikan matematika di Indonesia.

Banyak faktor yang mempengaruhi capaian belajar peserta didik (Hatie, 2003: 3). Prestasi belajar matematika bukan hanya merupakan fungsi tunggal yang dipengaruhi oleh satu faktor (Helma \& Edizon, 2017: 86). Belajar matematika peserta didik merupakan simultan dari kontribusi beragam komponen, dari kurikulum, sarana prasarana, kultur sekolah, sampai ke guru, kepala sekolah, dan peserta didik sendiri. Keseluruhan variabel tersebut memberikan dampak baik secara langsung maupun tidak langsung terhadap pencapaian prestasi belajar matematika peserta didik.

Rendahnya prestasi belajar matematika harus menjadi perhatian seluruh stakehoders pendidikan matematika (Sumaryanta, 2019: 553). Dari beragam faktor, salah satu faktor paling dominan yang mempengaruhi belajar matematika peserta didik adalah guru. Guru merupakan figur sentral dalam proses pendidikan dan pembelajaran (Leba \& Padmomartono, 2014: 13). Guru adalah unsur manusiawi pendidikan yang berinteraksi langsung membantu belajar peserta didik di kelas (Djamarah, 2010: 1) yang sangat menentukan keberhasilan pembelajaran di sekolah (Mulyasa, 2015: 35). Guru adalah sumber yang penting untuk mengembangkan identitas matematika peserta didik (Cobb \& Hodge, 2002). Kompetensi dan kinerja guru merupakan point sentral yang berpengaruh langsung terhadap kinerja belajar peserta didik.

Semua yakin bahwa guru memiliki andil yang sangat besar terhadap keberhasilan pembelajaran di sekolah (Mulyasa, 2015: 35). Akan tetapi sampai saat ini belum terdapat cukup penelitian yang menyatakan dengan sungguh-sungguh seberapa jauh keterkaitan kompetensi guru matematika dengan prestasi belajar peserta didik. Keterbatasan data menyebabkan program-program peningkatan kualitas pendidikan dari perspektif guru sering dilakukan hanya didasarkan asumsi dan pemikiran spekulatif sehingga tidak memberikan hasil optimal (Sumaryanta, dkk., 2018: 107). Penelitian- 
penelitian yang berorientasi pada kajian terhadap kompetensi dan kinerja guru penting dilakukan agar diperoleh gambaran yang tepat tentang profil guru dan kaitannya dengan capaian belajar peserta didik.

Penelitian ini dilaksanakan untuk mengidentifikasi seberapa besar sesungguhnya kontribusi kompetensi guru terhadap capaian belajar matematika peserta didik.Aspek penguasaan keilmuan metematika guru menjadi fokus utama penelitian ini. Temuan penelitian ini diharapkan dapat digunakan sebagai pijakan pengembangan program-program peningkatan kompetensi guru matematika sehingga terwujud guru matematika yang kompeten yang mampu mendorong peningkatan kualitas hasil belajar peserta didik.

\section{METODE PENELITIAN}

Penelitian ini merupakan penelitian ex post facto untuk menggali besarnya kontribusi kompetensi guru terhadap prestasi belajar peserta didik. Kompetensi utama guru yang dikaji dalam penelitian ini meliputi tiga hal esensial, yaitu: kemampuan matematika dasar guru, kemampuan guru menyelesaikan soal setara ujian nasional, dan kemampuan guru dalam menyelesaikan soal HOTs.Penelitian dilaksanakan pada bulan Maret sampai dengan November 2019.

Populasi penelitian ini meliputi seluruh guru SD, guru matematika SMP, guru matematika SMA, dan guru matematika SMK di Indonesia. Sampel penelitian ini terdiri dari 858 orang guru yang berasal dari 22 kabupaten/kota di Indonesia. Data penelitian ini dikumpulkan dengan teknik tes. Tes terdiri dari 3 (tiga) jenis, yaitu: tes kemampuan matematika dasar guru, tes kemampuan guru menyelesaikan soal setara ujian nasional, dan tes kemampuan guru menyelesaikan soal HOTs. Setiap tes dibuat berjenjang, yaitu tes untuk guru jenjang SD, tes untuk guru matematika jenjang SMP, tes untuk guru matematika SMA, dan tes untuk guru matematika SMK.

Data hasil penelitian ini dianalisis dengan teknik analisis regresi. Analisis regresi diawali dengan uji asumsi, meliputi: uji multikolinearitas, heteroskedastisitas, dan normalitas, dilanjutkan dengan uji kelayakan model, kemudian uji hipotesis. Setelah itu, analisis dilakukan untuk menentukan persamaan regresi dilanjutkan penentuan besar kontribusi kompetensi guru terhadap prestasi belajar peserta didik. Keseluruhan proses analisis regresi pada penelitian ini dilakukan dengan bantuan program pengolah data SPSS.

\section{HASIL PENELITIAN DAN PEMBAHASAN}

\section{Uji Prasyarat Analisis}

Sebelum melakukan analisis dengan regresi peneliti melakukan terlebih dahulu uji prasyarat analisis, meliputi: multikolinieritas, autokorelasi, heteroskedastisitas, dan normalitas.

\section{Multikolinearitas}

Hasil uji multikolinieritas, dapat dilihat pada Tabel 2 berikut.

Tabel 2. Output Uji Multikolinear

\begin{tabular}{|c|c|c|c|c|c|c|c|c|}
\hline \multirow{2}{*}{\multicolumn{2}{|c|}{ Model }} & \multicolumn{2}{|c|}{$\begin{array}{l}\text { Unstandardized } \\
\text { Coefficients }\end{array}$} & \multirow{2}{*}{$\begin{array}{c}\text { Standardized } \\
\text { Coefficients } \\
\text { Beta }\end{array}$} & \multirow[t]{2}{*}{$\mathrm{t}$} & \multirow[t]{2}{*}{ Sig. } & \multicolumn{2}{|c|}{$\begin{array}{l}\text { Collinearity } \\
\text { Statistics }\end{array}$} \\
\hline & & B & Std. Error & & & & Tolerance & VIF \\
\hline \multirow[t]{4}{*}{1} & (Constant) & 25.979 & .647 & & 40.159 & .000 & & \\
\hline & MatDasGuru & .013 & .011 & .080 & 1.204 & .230 & .684 & 1.463 \\
\hline & UNGuru & .055 & .010 & .382 & 5.717 & .000 & .667 & 1.499 \\
\hline & HOTsGuru & .014 & .015 & .054 & .892 & .373 & .814 & 1.229 \\
\hline
\end{tabular}


Nilai VIF untuk variabel MatDas, UNGuru, dan HOTsGuru adalah 1.463 dengan toleransi 0.684 , 1.499 dengan toleransi 0.667 , dan 1.229 dengan toleransi 0.814 . Karena nilai VIF dari kedua variabel tidak ada yang lebih besar dari 10 maka dapat dikatakan tidak terjadi multikolinieritas pada kedua variabel bebas tersebut.

\section{Uji Heteroskedastisitas}

Pengujian heteroskedastisitas dilakukan dengan membuat Scatterplot (alur sebaran) antara residual dan nilai prediksi dari variabel terikat yang telah distandarisasi. Hasil uji heteroskedastisitas dapat dilihat pada gambar Scatterplot, seperti pada Gambar 3di bawah ini.

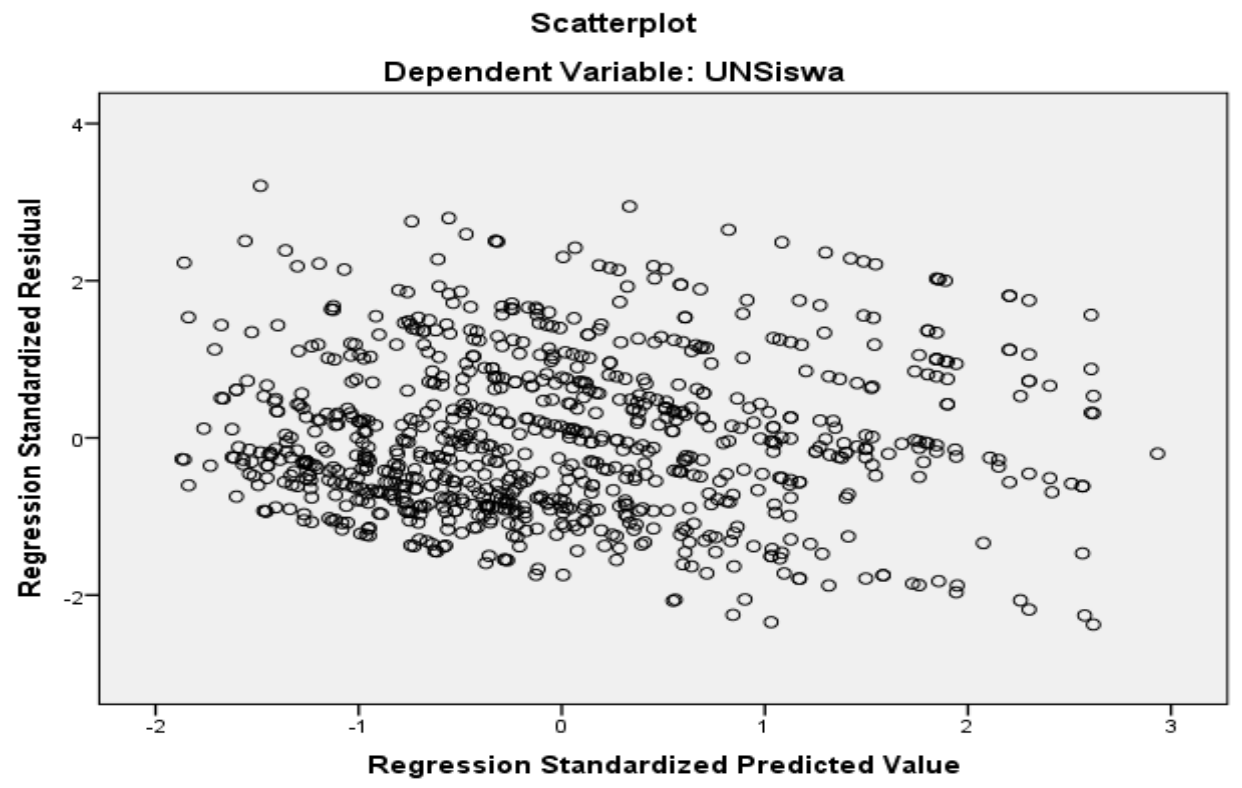

Gambar 3. Output Scratterplot

Dari gambar di atas terlihat bahwa sebaran titik tidak membentuk suatu pola/alur tertentu, sehingga dapat disimpulkan tidak terjadi heteroskedastisitas atau dengan kata lain terjadi homoskedastisitas. Asumsi klasik tentang heteroskedastisitas dalam model ini terpenuhi, yaitu terbebas dari heteroskedastisitas.

\section{Uji Normalitas}

Hasil uji normalitas dapat dilihat dari gambar Normal P-P Plot. Perlu diketahui bahwa asumsi normalitas yang dimaksud dalam asumsi klasik adalah (data) residual yang dibentuk model regresi linier terdistribusi normal, bukan variabel bebas ataupun variabel terikatnya. Kriteria sebuah (data) residual terdistribusi normal atau tidak dengan pendekatan Normal P-P Plot dapat dilakukan dengan melihat sebaran titiktitik yang ada pada gambar. Apabila sebaran titik-titik tersebut mendekati atau rapat pada garis lurus (diagonal) maka dikatakan bahwa (data) residual terdistribusi normal, namun apabila sebaran titik-titik tersebut menjauhi garis maka tidak terdistribusi normal.

Dari output analisis diperoleh Normal P-P Plot, disajikan pada Gambar 4 berikut. 




Gambar 4. Normal P-P Plot

Sebaran titik-titik dari gambar Normal P-P Plotdi atas relatif mendekati garis lurus, sehingga dapat disimpulkan bahwa (data) residual terdistribusi normal. Hasil ini sejalan dengan asumsi klasik dari regresi linier.

\section{Uji Kelayakan Model}

\section{Uji Keterandalan Model (Uji F)}

Uji keterandalan model atau uji kelayakan model atau yang lebih populer disebut sebagai uji $\mathrm{F}$ (ada juga yang menyebutnya sebagai uji simultan model) merupakan tahapan awal mengidentifikasi model regresi yang diestimasi layak atau tidak. Layak (andal) disini maksudnya adalah model yang diestimasi layak digunakan untuk menjelaskan pengaruh variabel-variabel bebas terhadap variabel terikat. Nama uji ini disebut sebagai uji F, karena mengikuti mengikuti distribusi F yang kriteria pengujiannya seperti One Way Anova.

Pengunaan software SPSS memudahkan penarikan kesimpulan dalam uji ini. Apabila nilai prob. F hitung (output SPSS ditunjukkan pada kolom sig.) lebih kecil dari tingkat kesalahan/error (alpha) 0,05 (yang telah ditentukan) maka dapat dikatakan bahwa model regresi yang diestimasi layak, sedangkan apabila nilai prob. F hitung lebih besar dari tingkat kesalahan 0,05 maka dapat dikatakan bahwa model regresi yang diestimasi tidak layak. Hasil uji $\mathrm{F}$ dapat dilihat pada Tabel 3di bawah ini.

Tabel 3. Output ANOVA

\begin{tabular}{|c|c|c|c|c|c|c|}
\hline \multicolumn{7}{|c|}{ ANOVA $^{a}$} \\
\hline \multicolumn{2}{|c|}{ Model } & $\begin{array}{l}\text { Sum of } \\
\text { Squares }\end{array}$ & df & $\begin{array}{l}\text { Mean } \\
\text { Square }\end{array}$ & $\mathrm{F}$ & Sig. \\
\hline \multirow[t]{3}{*}{1} & Regression & 15834.636 & 3 & 5278.212 & 105.311 & $.000^{\mathrm{b}}$ \\
\hline & Residual & 42802.636 & 854 & 50.120 & & \\
\hline & Total & 58637.272 & 857 & & & \\
\hline \multicolumn{7}{|c|}{ a. Dependent Variable: UNPeserta didik } \\
\hline \multicolumn{7}{|c|}{ b. Predictors: (Constant), HOTs, MatDas, UNGuru } \\
\hline
\end{tabular}

Nilai prob. F hitung (sig.) pada tabel di atas nilainya 0,0001 lebih kecil dari tingkat signifikansi 0,05 sehingga dapat disimpulkan bahwa model regresi linier yang diestimasi layak digunakan untuk pengaruh kemampuan matematika dasar guru, kemampuan guru menyelesaian soal UN, dan kemampuan guru menyelesaikan soal HOTs terhadap capaian nilai UN peserta didik. 


\section{Uji Koefisien Regresi (Uji $t$ )}

Uji $t$ dalam regresi linier berganda dimaksudkan untuk menguji apakah parameter (koefisien regresi dan konstanta) yang diduga untuk mengestimasi persamaan/model regresi linier berganda sudah merupakan parameter yang tepat atau belum. Maksud tepat disini adalah parameter tersebut mampu menjelaskan perilaku variabel bebas dalam mempengaruhi variabel terikatnya. Parameter yang diestimasi dalam regresi linier meliputi intersep (konstanta) dan slope (koefisien dalam persamaan linier). Pada bagian ini, uji $t$ difokuskan pada parameter slope (koefisien regresi) saja. Jadi uji $t$ yang dimaksud adalah uji koefisien regresi. Hasil pengujian dapat dilihat pada outputCoefficients ${ }^{\mathrm{a}}$ seperti padaTabel 4.

Tabel 4. Output Coefficients

\begin{tabular}{|c|c|c|c|c|c|c|c|c|}
\hline \multicolumn{9}{|c|}{ Coefficients $^{a}$} \\
\hline \multirow{2}{*}{\multicolumn{2}{|c|}{ Model }} & \multicolumn{2}{|c|}{$\begin{array}{c}\text { Unstandardized } \\
\text { Coefficients }\end{array}$} & \multirow{2}{*}{$\begin{array}{c}\text { Standardized } \\
\text { Coefficients } \\
\text { Beta }\end{array}$} & \multirow[t]{2}{*}{$\mathrm{t}$} & \multirow[t]{2}{*}{ Sig. } & \multicolumn{2}{|c|}{$\begin{array}{l}\text { Collinearity } \\
\text { Statistics }\end{array}$} \\
\hline & & $\mathrm{B}$ & Std. Error & & & & Tolerance & VIF \\
\hline \multirow[t]{4}{*}{1} & (Constant) & 28.527 & .751 & & 37.965 & .000 & & \\
\hline & MatDas & .023 & .012 & .066 & 1.876 & .061 & .680 & 1.470 \\
\hline & UNGuru & .037 & .011 & .122 & 3.255 & .001 & .611 & 1.638 \\
\hline & HOTs & .154 & .013 & .411 & 11.908 & .000 & .718 & 1.394 \\
\hline
\end{tabular}

Seperti uji $F$ yang dimudahkan dengan aplikasi SPSS, maka uji $t$ juga dapat dengan mudah ditarik kesimpulannya. Apabila nilai prob. $t$ hitung (output SPSS ditunjukkan pada kolom sig.) lebih kecil dari tingkat kesalahan (alpha) 0,05 (yang telah ditentukan) maka dapat dikatakan bahwa variabel bebas (dari $t$ hitung tersebut) berpengaruh signifikan terhadap variabel terikatnya, sedangkan apabila nilai prob. $t$ hitung lebih besar dari tingkat kesalahan 0,05 maka dapat dikatakan bahwa variabel bebas tidak berpengaruh signifikan terhadap variabel terikatnya.

Nilai prob. $t$ hitung dari variabel bebas MatDas sebesar 0,61 lebih besar dari 0,05 sehingga variabel bebas MatDas tidak berpengaruh signifikan terhadap variabel terikat UNPeserta didik pada taraf signifikansi 5\% atau dengan kata lain, Kemampuan matematika dasar guru tidak berpengaruh signifikan terhadap capaian UN peserta didik pada taraf keyakinan $95 \%$. Pengaruh variabel bebas UNGuru terhadap variabel terikat UNPeserta didik, karena nilai prob. $\mathrm{t}$ hitung $(0,001)$ yang lebih kecil dari 0,05 dapat dikatakan bahwa variabel bebas kemampuan guru dalam menyelesaikan soal UN berpengaruh signifikan terhadap variabel terikat caaian nilai UNPeserta didik pada alpha 5\% atau dengan kata lain, kemampuan guru dalam menyelesaikan soal UN berpengaruh berpengaruh signifikan terhadap capaian UNPeserta didik pada taraf keyakinan 95\%. Terakhir untuk variabel HOTsGuru, nilai prob. $t$ hitung dari variabel bebas HOTsGuru sebesar 0,000 yang lebih kecil dari 0,05 sehingga variabel bebas kemampuan guru dalam menyelesaikan soal HOTs berpengaruh signifikan terhadap variabel terikat UNPeserta didik pada alpha 5\% atau dengan kata lain, kemampuan guru menyelesaikan soal HOTs tidak berpengaruh signifikan terhadap capaian UN peserta didik pada taraf keyakinan $95 \%$.

\section{Pengujian Hipotesis Simultan}

Ho : Tidak ada pengaruh MatDas, UNGuru dan HOTsGuru terhadap UNPeserta didik Ha : Ada pengaruh MatDas, UNGuru dan HOTsGuru terhadap UNPeserta didik

Pengambilan keputusan (berdasarkan probabilitas): Jika probabilitas > 0,05 maka $\mathrm{H}_{\mathrm{o}}$ diterima, sedangkan jika probabilitas $<0,05$ maka $\mathrm{H}_{\mathrm{o}}$ ditolak. Pengujian hipotesis simultan ini juga memanfaatkan output ANOVA pada Tabel 3. 
Tabel 3 menunjukkan bahwa nilai probabilitas adalah sebesar 0,00 (kurang dari 0,05) sehingga $\mathrm{H}_{\mathrm{o}}$ ditolak. Artinya, pengaruh MatDas, UNGuru dan HOTsGuru secara simultan terbukti secara signifikan mempengaruhi UNPeserta didik sehingga hipotesis alternatif $\left(\mathrm{H}_{\mathrm{a}}\right)$ diterima.

\section{Persamaan Regresi}

Penyusunan persamaan regresi didasarkan pada output coefficients pada Tabel 3. Misalkan $Y^{\prime}=$ UNPeserta, $X_{1}=$ MatDas, $X_{2}=U N G u r u, d a n X_{3}=$ HOTsGuru. Penentuan persamaan regresi didasarkan pada nilai $B$ kolom unstandardized Coeficients, sehingga dengan memperhatikan output di atas diperoleh persamaan regresi berikut.

$$
Y^{\prime}=28.527+0.23 X_{1}+0.037 X_{2}+0.154 X_{3}
$$

Konstanta sebesar 28.527 berarti bahwa tanpa adanya pengaruh $X_{1}, X_{2}$, dan $X_{3}$, maka nilai $Y$ adalah 28.527. Jika terjadi perubahan 1 unit variabel $X_{1}$, maka $Y$ akan berubah sebesar 0.23 , dengan catatan $X_{2}$ dan $X_{2}$ ditahan konstan. Jika terjadi perubahan 1 unit variabel $X_{2}$, maka $Y$ akan berubah sebesar 0.037 , dengan catatan $X_{1}$ dan $X_{3}$ ditahan konstan. Jika terjadi perubahan 1 unit variabel $X_{3}$, maka $Y$ akan berubah sebesar 0.154 , dengan catatan $X_{1}$ dan $X_{2}$ ditahan konstan.Jika dinyatakan dalam bentuk standard, maka persamaan regresi adalah:

$$
Z_{y}^{\prime}=0.066 Z_{1}+0.122 Z_{1}+0.411 Z_{3}
$$

Dari persamaan standard di atas dapat disimpulkan bahwa variabel yang memiliki kontribusi terbesar adalah $X_{2}$ (UNGuru), dan kontribusi terkecil adalah X3 (HOTsGuru). Dengan kata lain, variabel yang memiliki kontribusi terbesar terhadap capaian UNPeserta didik adalah kemampuan guru dalam menyelesaikan soal setara UN, dan variabel yang memiliki kontribusi terkecil terhadap capaian UNPeserta didik adalah kemampuan guru dalam menyelesaikan soal HOTs.

\section{Kontribusi kemampuan guru terhadap prestasi peserta didik}

Besar kontribusi kemampuan guru terhadap prestasi peserta didik dapat ditentukan dengan memanfaatkan output summary ${ }^{b}$ yang disajikan pada Tabel 5berikut.

Tabel 5. Output Model Summary ${ }^{b}$

\begin{tabular}{|l|c|c|c|c|}
\hline Model & $\mathrm{R}$ & $\mathrm{R}$ Square & $\begin{array}{c}\text { Adjusted R } \\
\text { Square }\end{array}$ & $\begin{array}{c}\text { Std. Error of } \\
\text { the Estimate }\end{array}$ \\
\hline 1 & $.520^{\mathrm{a}}$ & .270 & .267 & 7.07956 \\
\hline a. Predictors: (Constant), HOTs, MatDas, UNGuru \\
\hline \multicolumn{2}{|l|}{ b. Dependent Variable: UNPeserta didik } \\
\hline
\end{tabular}

Dari outputs di atas diperoleh Adjusted $R$ Square $=0.270$. Dengan demikian dapat dinyatakan bahwa kontribusi $X_{1}, X_{2}$, dan $X_{3}$ terhadap $Y$ sebesar $26.7 .0 \%$, dan sisanya dipengaruhi oleh faktor lainnya. Dengan kata lain dapat bahwa kontribusi MatDas (kemampuan matematika dasar guru), UNGuru (kemampuan guru dalam menyelesaikan soal setara UN), dan dan HOTsGuru (kemampuan guru dalam menyelesaikan soal HOTs terhadap UNSpeserta didik (capaian nilai UN Peserta didik) sebesar 26.7.0\%, dan sisanya dipengaruhi faktor lainnya.

Temuan-temuan di atas menunjukkan bahwakompetensi guru memberi kontribusi signifikan terhadap prestasi belajar peserta didik. Kemampuan matematika dasar guru, kemampuan guru menyelesaikan soal setara ujian nasional, dan kemampuan guru menyelesaikan soal HOTs secara simultan berkontribusi langsung terhadap pencapaian nilai prestasi belajar peserta didik sebesar 26.7.0\%. Hasil ini selaras dengan pendapat Hattie (2003: 3) yang menyatakan bahwa guru merupakan salah satu faktor dominan yang mempengaruhi capaian belajar peserta didik. 
Penelitian ini menunjukkan bahwa pengetahuan guru tentang konten matematika berpengaruh langsung terhadap pencapaian belajar peserta didik. Hal ini selaras dengan pendapat Campbell, dkk, (2014: 423 - 424) yang menyatakan bahwa prestasi belajar matematika peserta didik sangat dipengaruhi pengetahuan guru, baik tentang konten maupun pedagogik, juga kepercayaan guru tentang belajar dan pembelajaran, serta kepedulian guru terhadap peserta didik. Oleh karena itu penting bagi setiap guru meningkatkan penguasaan keilmuannya sebagai prasyarat agar guru mampu membantu peserta didiknya mencapai prestasi optimal.

Hasil penelitian ini juga menunjukkan bahwa perhatian seluruh stakeholders pendidikan untuk mendorong peningkatan kualitas guru sangat penting dilakukan. Peningkatan kualitas guru sangat diperlukan untuk menjamin layanan pendidikan berkualitas (Panggabean \& Himawan, 2016:1). Guru merupakan ujung tombak dalam meningkatkan kualitas pendidikan (Daryanto, 2013: 258). Oleh karena itu, pemberdayaan guru penting dilakukan dalam rangka untuk meningkatkan pengetahuan, keterampilan dan sikap yang diperlukan untuk mendukung penyelesaian tugas mulia mereka sebagai kontributor utama belajar peserta didik (Kimwarey, Chirure, \& Omondi, 2014: 51). Tanpa hadirnya guru-guru yang kompeten sulit terwujud layanan pendidikan yang berkualitas.

Kontribusi langsung kompetensi guru terhadap prestasi belajar peserta didik bermakna bahwa setiap upaya meningkatkan capaian belajar matematika peserta didik harus didukung dengan peningkatan kompetensi guru. Hal ini selaras dengan pendapat (Cobb \& Hodge, 2002) yang menyatakan bahwa guru adalah sumber yang paling penting untuk mengembangkan identitas matematika peserta didik. Mereka mempengaruhi cara-cara di mana peserta didik memikirkan diri mereka sendiri di kelas (Walshaw, 2004; Anthony\& Walshaw, 2009: 150). Dengan demikian, semakin tinggi kemampuan keilmuan yang dimiliki guru akan semakin berdampak positif bagi pencapaian belajar peserta didik, termasuk hasil UN matematika.

Kehadiran guru-guru yang berkualitas dapat mendorong peserta didik mencapai prestasi setingkat atau bahkan lebih tinggi dari potensinya. Pendidikan bukan tentang mengisi ember tetapi tentang menyalakan api (Kabadayi, 2016: 12). Pembelajaran di kelas bukanlah penciptaan pengetahuan untuk peserta didik, bukan pula pemindahan pengetahuan guru pada peserta didik, tetapi upaya menumbuhkan "apa yang sudah ada" pada peserta didik agar berkembang optimal (Stanic, 1986: 34). Kemampuan guru yang baik akan memberikan kontribusi penting bagi optimalisasi potensi peserta didik.

Mengingat peranan strategis guru dalam setiap upaya peningkatan mutu, relevansi, dan efisiensi pendidikan, maka pengembangan profesionalisasi guru merupakan kebutuhan (Saud, 2017: 97). Setiap upaya peningkatan kualitas pendidikan tidak dapat dilepaskan dari berbagai hal yang berkaitan dengan eksistensi guru (Daryanto, 2013: 1). Menjadi seorang guru berarti menghadapi tantangan dan mengembangkan keterampilan untuk mengelola dan memengaruhi perubahan (Poom-Valickis, dkk., 2013: 15-23). Revolusi industri dengan segala implikasi perubahannya benar-benar membutuhkan hadirnya guru-guru yang kompeten di kelas yang mampu mempersiapkan peserta didik menghadapi kehidupannya dimasa kini dan masa depan.

\section{KESIMPULAN DAN SARAN}

Berdasarkan hasil penelitian ini dapat disimpulkan bahwa secara simultan kemampuan matematika dasar guru, kemampuan guru menyelesaikan soal UN dan HOTs berkontribusi langsung (secara sangat signifikan/sig. 0.00) terhadap pencapaian nilai UN peserta didik, sebesar $26.7 \%$, dengan persamaan regresi $Y=28.527+0.023$ MatDas $+0.037 U N+0.154$ HOTs.Hasil ini selaras dengan temuan beberapa pakar lain yang menunjukkan bahwa guru merupakan salah satu faktor dominan yang mempengaruhi capaian belajar peserta didik. Temuan ini dapat dimaknai pula bahwa setiap upaya meningkatkan capaian belajar matematika peserta didik harus didukung dengan peningkatan kompetensi guru.Kehadiran guru-guru yang berkualitas dapat mendorong peserta didik mencapai prestasi setingkat atau bahkan lebih tinggi dari potensinya. Di sisi yang lain, tanpa hadirnya guru-guru yang kompeten sulit terwujud layanan pendidikan yang berkualitas sehingga berdampak peserta didik gagal mencapai prestasi sesuai potensi yang dimiliki. 
Berdasarkan hasil penelitian ini upaya meningkatkan kemampuan guru matematikaperlu terus dilakukan sehingga guru dapat memberikan kontribusi lebih positif bagi pencapaian prestasi belajar matematika peserta didik. Setiap guru penting untuk meningkatkan penguasaan keilmuannya sebagai prasyarat agar guru mampu membantu peserta didiknya mencapai prestasi optimal. Perhatian seluruh stakeholders pendidikan untuk mendorong peningkatan kualitas guru juga sangat penting dilakukan. Selain itu, perlu juga dilakukan pemetaan menyeluruh kompetensi guru matematika sehingga diperoleh data yang lebihkomprehensif dan akurat sebagai dasar pijakan pengembangan dan pelaksanaan program-program pembinaan guru matematika di Indonesia.Program pembinaan guru berdasarkan peta data kompetensi guru yang tepat diharapkan dapat mewujudnyatakan guru-guru matematika Indonesia yang berkualitas secara lebih optimal.

\section{DAFTAR PUSTAKA}

Anthony, G. \& Walshaw, M. 2009. Characteristics of Effective Teaching of Mathematics: A View from the West. Journal of Mathematics Education, 2(2), 147-164

Campbell, P.F., dkk. (2014). The Relationship Between Teachers' Mathematical Content and Pedagogical Knowledge, Teachers' Perceptions, and Student Achievement. Journal for Research in Mathematics Education, 45(4) 419-459

Cobb, P., \& Hodge, L. L. (2002). A relational perspective on issues of cultural diversity and equity as they play out in the mathematics classroom. Mathematical Thinking and Learning, 4 (1) 249-284

Daryanto. 2013. Standar Kompetensi dan Penilaian Kinerja Guru Profesional. Yogyakarta: Penerbit Gava Media

Djamarah, S.B. 2010. Guru \& Anak Didik dalam Interaksi Edukatif: Suatu Pendekatan Teoritis Psikologis. Jakarta: PT Rineka Cipta

Hattie, J. (2003). Teachers Make a Difference: What is the research evidence? Australian Council for Educational Research Annual Conference on: Building Teacher Quality

Helma \& Edizon. 2017.Faktor-faktor yang Mempengaruhi Hasil Belajar Matematika Peserta didik untuk Penerapan Bahan Ajar Kontekstual Mengintegrasikan Pengetahuan Terkait dan Realistik. Jurnal Eksakta Pendidikan (JEP), 1(1), 86 - 92

Kabadayi, A.I. (2016). A Suggested In-service Training Model Based on Turkish Preschool Teachersí Conceptions for Sustainable Development. Journal of Teacher Education for Sustainability, 18(1), $5-15$

Kimwarey M. C., Chirure H.N; \& Omondi M. (2014). Teacher Empowerment in Education Practice: Strategies, Constraints and Suggestions. IOSR Journal of Research \& Method in Education (IOSR-JRME), Volume 4, Issue 2 Ver. II (Mar-Apr. 2014), PP 51-56

Leba, U.T.I \& Padmomartono, S. 2014. Profesi Kependidikan. Yogyakarta: Penerbit Ombak

Morrar, R., Arman, H., \& Mousa, S. 2017. The Fourth Industrial Revolution (Industry 4.0): A Social Innovation Perspective. Technology Innovation Management Review, 7(11). 12 - 20

Mulyasa. 2015. Menjadi Guru Profesional: Mencipatakan Pembelajaran Kreatif dan Menyenangkan. Bandung: PT Remaja Rosdakarya Offset

Panggabean, M.S. \& Himawan, K.K. (2016). The Development of Indonesian Teacher Competence Questionnaire. Journal of Educational, Health and Community Psychology, 5(2),1 - 15

Poom-Valickis, K., Saarits, I., Sikka, H., Talts, L., Veisson, M. (2013). Professional Education of Teachers $\tilde{n}$ Problems and Perspectives. The Estonian Case. Journal of Teacher Education and Training, Vol. 3, p. $15-23$

Saud, U.S. 2017. Pengembangan Profesi Guru. Bandung: Penerbit Alfabeta

Sholihah, D.A. \& Mahmudi, A. 2015. Keefektifan Experiential Learning Pembelajaran Matematika MTS Materi Bangun Ruang Sisi Datar. Jurnal Riset Pendidikan Matematika, 2 (2), 175 185

Sidiq, M. dkk. 2019. Media Pembelajaran Matematika Menyongsong Industry 4.0: Tinjauan Literatur Sistematis untuk Analisis Kebutuhan.Conference Paper, available at https://www.researchgate.net/publication/330506130 
Stanic, G.A. (1986). Mental Discipline Theory and Mathematics Education. For the Learning of Mathematics M Publishing Association, Montreal, Quebec, Canada

Sumaryanta. 2019. Pemetaan Hasil Ujian Nasional Matematika. Indonesian Digital Journal of Mathematics and Education, 6(1), $543-557$

Sumaryanta, dkk. 2018. Assessing Teacher Competence and It's Follow-up to Support Professional Development Sustainability. Journal of Teacher Education for Sustainability, 20(1) $106-$ 123.

Warohidah, A.R.\& Kusuma, A.B. 2019. Perkembangan Era Revolusi Industri 4.0 dalam Pembelajaran Matematika. Prosiding Sendika, 5(1), 109 - 114 